\title{
Corporate Social Responsibility and Its Relevance to Accounting
}

\author{
Saeid Homayoun ${ }^{1}$, Zabihollah Rezaee ${ }^{2} \&$ Zahra Ahmadi $^{3}$ \\ ${ }^{1}$ Assistant Professor of Accounting, Department of Business and Economic Studies, Faculty of Education and \\ Economics, University of Gävle, Sweden \\ 2 Thompson-Hill Chair of Excellence \& Professor of Accountancy, Fogelman College of Business and \\ Economics, The University of Memphis, USA \\ ${ }^{3} \mathrm{PhD}$ Candidate in Marketing, Department of Business and Economic Studies, Faculty of Education and \\ Economics, University of Gävle, Sweden \\ Correspondence: Saeid Homayoun, PhD, Department of Business and Economic Studies, Faculty of Education, \\ and Economics, University of Gävle, Sweden, Kungsbäcksvägen 47, 80176 Gävle, Sweden. Tel: 46-26-648-500. \\ E-mail: sadhon@hig.se
}

Received: June 22, 2015 Accepted: July 5, 2015 Online Published: November 29, 2015

doi:10.5539/jsd.v8n9p178

URL: http://dx.doi.org/10.5539/jsd.v8n9p178

\begin{abstract}
Corporate social responsibility (CSR) has been extensively and inconclusively debated in the literature. In this essay, we examine the development of CSR by both reviewing the evolution of the conceptual framework and models of CSR and discussing social responsibility accounting and auditing. We conclude that both business and academic communities worldwide should pay closer attention to CSR and its components of economic, social, and environmental performance. Business organizations worldwide are just starting to recognize the importance of quality as it relates to CSR and the link between profitability and social behavior. Justifications for CSR are fulfilling moral obligations, maintaining a good reputation, ensuring sustainability and licensing to operate, and creating shared value for all corporate stakeholders.
\end{abstract}

Keywords: corporate social responsibility, social accounting, auditing

\section{Introduction}

Corporate social responsibility (CSR) is an integral component of corporate governance, particularly when there is a conflict between the social goal of benefiting society and the corporate goal of maximizing profits. The existence and persistence of such a conflict requires corporations to establish CSR policies and programs to ensure that their boards of directors and senior executives set an appropriate tone at the top, taking social interests seriously. Currently, corporate leaders face the challenge of operating responsibly according to certain moral standards. CSR is becoming an inseparable part of business as more investors worldwide prefer to invest in socially responsible companies. Although the term 'corporate social responsibility' seems to be new, the business literature indicates that the concept has evolved over recent decades, along with social, political, and environmental developments. CSR demands that various local, national, and international organizations compile standards for nonfinancial reports. There is an unprecedented move toward disclosing both financial and nonfinancial information on key performance indicators of economic, social, and environmental activities. The Organisation for Economic Co-operation and Development (OECD) defines the purpose of a CSR program as "to encourage the positive contributions that multinational enterprises can make to economics, environmental and social progress and to minimize the difficulties to which their various operations may give rise" (OECD, 2003). This definition focuses on two important aspects of a CSR program, namely the creation of social value through corporate activities (social value-added activities) and the avoidance of conflicts between corporate goals and societal goals (societal consensus).

The primary purpose of this essay is threefold. First, we examine the evolution of CSR and its current status in business organizations worldwide. Second, we present models and conceptual frameworks of CSR and its best practices. Finally, we address ways to effectively disclose CSR performance information through social responsibility accounting and auditing. Global investors are currently demanding and regulators are mandating that business organizations disclose both financial and nonfinancial information about their economic, social, and environmental activities (Rezaee, 2015). This move toward the reporting of multiple key performance 
indicators is intended to satisfy the needs of all stakeholders, including investors, creditors, customers, employees, government, and society. Thus, businesses are now responsible for creating shareholder value and protecting the interests of other stakeholders. To effectively compete in global financial markets, corporations are paying more attention to CSR and sustainability.

\section{Corporate Social Responsibilities}

There has been growing international interest in corporate social responsibilities, including environmental, social, and governance (ESG) issues (United Nations Environment Progamme Finance Initiative and the UN Global Compact (UNEP FI), 2006). ESG issues can affect the company's performance, supply chain management, and investment portfolios, and thus should be considered in assessing operating and investment decisions. To address this important global issue, in 2005 the United Nations Secretary-General invited a group of representatives from 20 investment organizations in 12 countries to establish a set of global best practice principles for responsible investment (UNEP FI, 2006; United Nations Principles for Responsible Investment (PRI), n.d.). The PRI are voluntary and aspirational rather than prescriptive, providing a framework for incorporating ESG issues into investment decision making and ownership practices (UNEP FI, 2006). Compliance with the PRI is expected to lead not only to a more sustainable financial return but also to a close alignment of the interests of investors with those of global society at large. The PRI, which provide a common framework for the integration of ESG issues, consist of:

i. Integration of ESG issues into the investment analysis and decision-making process

ii. Incorporation of ESG issues into investment ownership policies and practices

iii. Promotion of appropriate disclosure on ESG issues by the entities in which institutional investors invest

iv. Promotion of acceptance and implementation of the principles within the investment industry

v. Collaboration among institutional investors to enhance the effectiveness of implementing the principles

vi. Reporting on initiatives, activities, and progress toward implementing these principles (PRI, n.d.).

CSR requires business organizations to take initiatives to advance some social good beyond their own interests and compliance with applicable regulations. Simply put, CSR means enhancing corporations' positive impacts and minimizing their negative effects on society, minimizing harm to society and the environment and creating positive impacts on the community, environment, employees, customers, and suppliers. The true measure of success for corporations should be determined not only by reported earnings, but also by their governance, social responsibility, ethical behavior, and environmental initiatives. Organizations are required not only to maximize profit and economic output but also to include all environmental aspects and social services. Therefore, all socially responsible organizations must fulfill four types of social responsibilities:

i. Voluntary or philanthropic responsibilities: advantages and benefits a business provides to society, including support for projects aimed at improving the life of the local community.

ii. Moral responsibilities: corporate activities expected to be done for society without any direct legal conditions or limitations.

iii. Legal responsibilities: regulations corporations must obey that were established to protect society.

iv. Economic responsibilities: both supplying required services and goods for society and offering these services and goods at an affordable price and making profit for investors (Rahahleh \& Sharairi, 2008).

Advantages of CSR are:

i. CSR reduces direct costs (energy, material, time loss, etc.).

ii. CSR increases employee productivity (increasing motivation and reducing absenteeism).

iii. CSR can diminish managerial risks.

iv. CSR promotes corporate competitiveness (Pettenella, 2010).

Gray, Owen, \& Maunders (1987) discussed the role of conventional accounting in result reports and asserted that instead of basing accountability on possession it is better to consider beneficiaries. Rubenstein (1992) went further, expressing that a new social contract is required between an organization and its beneficiaries. 


\subsection{Evolution of Social Responsibility in the Business Literature}

Although CSR seems to be a new concept in the business world, the literature shows that the concept has been around for decades. Terminology has changed over the years; this concept has evolved along with social, economic, and business developments. Global extended communication, global trends, and regulation changes have influenced the concept at the international level. We summarize the evolution of CSR from 1920 up to the current decade in the following sections.

\subsubsection{0 through the $1950 \mathrm{~s}$}

Since 1920, business managers have paid more attention to some definitions of responsibility and responsible performance (Windsor, 2001). Bowen (1953) conceptualized CSR as reflecting decisions and approaches that are desirable for society according to social values and goals. Carroll named Bowen "Father of corporate social responsibility" and considered his attempts as the initiation of a new and novel period of CSR (Carroll, 1999). Bowen had a wide view of business responsibility that included responsibility, stewardship, social auditing, and corporate citizenship (Windsor, 2001).

\subsubsection{The $1960 \mathrm{~s}$}

Studies from the 1960s were about disclosure of CSR. Carroll (1991) stated that in this decade multiple efforts were made to configure and conceptualize CSR and some of the famous authors emerged in this decade. Davis (1973) pointed out that some socially responsible decisions could be justified as a good chance to make long-term profit. It seems CSR of the 1960s showed that social responsibility reflects the human and economic bases of society. Additionally, it emphasized that resources must be used to increase social disclosure, not to make profit for individuals and companies. Walton (1967) emphasized that CSR is a kind of voluntary behavior.

\subsubsection{The $1970 \mathrm{~s}$}

In this period, CSR included focusing on the minimum in corporate social responsibility, according to Friedman (1970). His famous, controversial ideas are still discussed in current debates about CSR. Walton (1967) discussed the notion that CSR could be considered a dynamic part of issuing social certificates. Sethi (1975) proposed a three-level model for corporate social performance. This model differentiated different behaviors of companies:

$$
\begin{aligned}
\text { i. } & \text { Social liability (answer to market and legal constraints) } \\
\text { ii. } & \text { Social responsibility (equivalent to social norms) } \\
\text { iii. } & \text { Social accountability (social compatibility and participation). }
\end{aligned}
$$

\subsubsection{The $1980 \mathrm{~s}$}

This decade has been described as the period of a "more responsible attitude toward corporate guidelines" (Freeman, Wicks, \& Parmar, 2004). Freeman's idea led to the emergence of stakeholder theory (Windsor, 2001). Meeting the needs of beneficiaries and stakeholders is related to corporate performance. Stakeholder theory was the dominant paradigm of CSR during this decade. Carroll (1991) believed that during the 1980s the main focus was on the development of new definitions, including defining CSR, introducing new routes for future research to replace new concepts in literature, defining corporate social accountability, determining commercial behavior, and stakeholder theory. Tuzzolino and Armandi (1981) reported the development of new trends for evaluating CSR by using novel conceptual frameworks, which are a significant tool to measure corporate social performance. With the emerging global debates about sustainable development during this decade came some favorable reports about the relationship between sustainable development and economic growth. Additionally, researchers identified the direction of future discussion and raised some questions about whether CSR yields profits, which offered support for CSR.

\subsubsection{The 1990s}

During this decade no special effort was done to develop definitions of CSR, but the concept was central to stakeholder theory, business ethics, and corporate citizenship (Carroll, 1999). Wood (1991) importantly introduced the corporate social performance model and developed CSR content; the main focus of his model was results or performance. Wood's conceptual framework and Carroll's responsibility pyramid are among the basic contributions of this period (Windsor, 2001). These conceptual models will be described in the next section. During this decade, the beneficiary theory was more popular than the stakeholder theory, expanding on various concepts of corporate social performance. Also, in the late 1990s stakeholders' activities related to social and environmental dimensions focused on financial performance and related risks. Good behavior and desirable manners reduce stakeholders' risks. Global dominance of corporate social performance, along with the role of 
governments and businesses, were stable during this decade. Solomon (1994, p. 337) pointed out that currently corporations are the most powerful entities in the world, so they are expected to have a wide range of social responsibility. Carroll (1999) recommended that corporate social performance (as the attitude of the new millennium) is fundamental to the approach and language of business. This is the basis of many other theories that take into account growing public expectations of today's corporations.

\subsubsection{The New Millennium (Twenty-First Century)}

Following on the financial disgrace and collapse of such companies as Enron around 2001, debates about the place of CSR in the world economy, especially international companies, expanded to include social and environmental conditions (Smith, 2003). Along with development of global trade, recent literature focuses on more disclosures at the international level. During the new century, significant international development of CSR occurred, accompanied by global attention to human, social, and environmental rights. Recently, academic researchers in the field of business have paid more attention to CSR. Environmental and social responsibilities are mentioned in some legal and political documents. Additionally, they are attracting more attention at the international level. Currently, corporate managers have a challenging and dynamic duty to recruit persons with social and moral standards to be responsible for commercial operations. Growing pressure for social responsibility is a significant challenge for companies. Companies, especially those working in global markets, focus on increasing stakeholders' value, but they must balance social, environmental, and economic elements.

In summary, the evolution of CSR started in 1930 when debates about the role of corporations and executives emerged. Bowen (1953) argues that CSR programs initiate and undertake activities that are desirable for society in compliance with social values and goals. Bowen initiated a wide perspective about business responsibility that included responsibility, stewardship, social audit, and corporate citizenship (Windsor, 2001). The business literature of the 1960s promoted the recognition of CSR by business organizations and the disclosure of such responsibility to shareholders (Carroll, 1991). During the 1970s, the idea of focusing on protecting the interests of all stakeholders, including shareholders, was promoted as part of CSR (Friedman, 1970). The 1990s witnessed the era of the development of conceptual frameworks and models for CSR based on Wood's "conceptual framework" and Carroll's "responsibility pyramid" (Windsor, 2001), as well as the international acceptance of CSR.

\section{Conceptual Frameworks and Models for Corporate Social Responsibility}

Generally, two common conceptual models are mentioned for CSR, the Carroll model from 1979 and the Wood model from 1991. For the past 20 or 30 years researchers have debated corporate social responsibility. Various concepts originate from fundamental hypotheses concerning what to include in CSR. Frankental (2001) stated that CSR is an ambiguous term that reflects different meanings for different individuals. Therefore, CSR does not have a universally agreed upon definition. What follows are various researchers' judgements:
i. Social responsibility is a misleading term (Lee, 2008).
ii. Social responsibility is an ambiguous and incomplete term (Preston \& Post, 1975).
iii. Social responsibility is a term with divergent definitions (Votaw, 1973).
iv. Social responsibility is a term without theoretical integrity and empirical research (Defillipi, 1982).
v. Social responsibility is a term without a dominant paradigm (Jones, 1983).
vi. Social responsibility is a term vulnerable to subjective judgments and values (Aupperle, 1984).

Clarkson (1995) stated that the main problems are the lack of attractive definitions for CSP and CSR and the lack of public agreement about the meaning of the available terms from the practical and managerial points of view. Some managers challenge the term CSR, wondering what the meaning of "social" is and what the relationship between "social" and business activities is. Multiple ways to conceptualize CSR have been described in recent literature. In this essay, two conceptual models are mentioned briefly. As Carroll (1999) explains, his model introduced a four-part definition of CSR, named CSP. Wood (1991) defined the second model according to a general framework. Her model concentrates on responsible behavior, impressibility, and operational results.

\subsection{Carroll's Conceptual Model (1979-1991)}

Carroll differentiated among four types of responsibilities: economic, legal, moral, and philanthropic. Economic responsibility includes return on investment for owners and stakeholders, job opportunities, fair payment of employees, exploration of new resources, propagation of developed technology, innovation, and offering services and products. According to this view, enterprises are economic institutions in society; their roles are predicated on the responsibilities mentioned. Legal responsibility includes obedience to laws. Although regulations require 
certain behavior of companies, it is difficult for companies to be sure about compliance with laws. Compliance may even cause loss of opportunities because it limits commercial behavior. The third type, moral responsibility, overcomes regulation constraints by forming a moral character by which companies are able to survive (Solomon, 1994). A business with a moral policywill perform fairly and correctly. Moral responsibility includes activities not defined by law but rather designed to respect the public and prevent social damages and losses. Such responsibilities originate from an attention to human rights (Novak, 1996). These ideas are based on the belief that society and corporations are interwoven according to an innate and inner method (Frederick, 1994). This type of responsibility is the most controversial one and has multiple limitations. Its application contrasts with economic trends and profit making of businesses. The multi-dimensional Carroll social responsibility pyramid is shown in Figure 1.

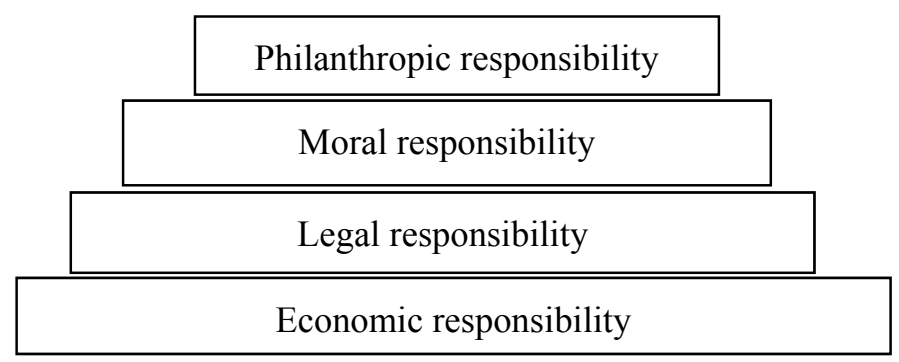

Figure 1. Carroll responsibility pyramid

The base of this pyramid is economic responsibility, while its vertex reflects philanthropic responsibility. Legal and economic responsibilities are essential to the social dimension. Social responsibility is expected by society, while philanthropic responsibility is desirable, according to the social dimension. Each of these responsibilities constitutes one of the fundamental elements of CSR. Dimensions of responsibility change depending on corporate industry, corporate responsible performance, and responsibility guidelines. Although Carroll's conceptual model has been very useful, responsibility dimensions are limited. Clarkson (1999) stated that the Carroll conceptual model was very complicated to examine and didn't help with the development of methodology to collect, organize, and evaluate corporate information.

\subsection{Wood's Conceptual Model (1991)}

Wood extended CSP beyond a catalog of the various types of responsibility to evaluate dimensions related to the motivational bases of responsible behavior, responsibility processes, and operational results. She considered CSP to be a result of obedience to the basic disciplines of CSR and refined the preliminary hypotheses. Her model developed the research areas of social responsibility. According to this model, responsibility forms a practical dimension which needs motivational and directional elements for social responsibility.

1) Bases of CSR

i. Fundamental bases

ii. Organizational bases

iii. Personal bases

2) Processes of CSR

i. Environmental assessment

ii. Beneficiaries assessment

iii. Management dimensions

3) Outcomes of corporate behavior
i. Social effects
ii. Social plans
iii. Social attitudes

Outcomes of corporate behavior are advantageous for the direct evaluation of CSR. According to the Wood model, outcomes are classified into three groups: social effects, corporate behavior, and plans; attitudes 
developed by companies for social dimensions and beneficiaries' profit are used by companies to administer responsibility. Whether corporate behavior has negative or positive impacts must be examined objectively. Meehan et al. (2006) pointed out that although the Wood model played an important role in research, it was unsuccessful in investigating the practical needs of managers to administer CSR and evaluate basic effects. In brief, since both the model and framework are conceptual, they are likely to develop theory and research in the field instead of having a practical impact. The dynamic and complicated nature of social environments that modern organizations encounter reflects the necessity for continuous management of beneficiaries. It is very hard to control such a complicated network, so a social responsibility management model identifying changes and resolving the needs of various groups of beneficiaries requires continuous supervision and a dynamic method.

\subsection{Social Responsibility Accounting}

Reports submitted by financial accounting systems reflect a company's performance according to certain perspectives, consider profitability and financial power of the business as a success or failure index, and pay more attention to making profit for such groups as:

- Active or passive investors

- Business managers

- Active or passive creditors

- Governmental organizations

- Customers

- Salespersons

To counter the lack of attention to social benefits and the effect of business practices on the environment, by the 1960s a new concept called social responsibility accounting was proposed in the theoretical field of accounting. Authors from Canada and Australia (e.g. Anderson, 1989) mentioned this concept in their writing. Jerry Anderson could be called the father of this field of accounting. In the United States, social responsibility accounting emerged in the 1970s when the American Accounting Association established a committee to evaluate the obstacles to and difficulties of measuring and reporting social responsibility (Committee on Social Measurement, 1977). Baron (2001) mentioned that using CSR in a firm can lead to attracting customers and can provide a good business strategy. Now, after four decades, the debate over social responsibility is still in its infancy. Most papers have been descriptive, have not focused on administrative problems, and have not provided suitable approaches for managers.

The current business environment contains risks for accounting and accountants. With the increase in the importance of environmental issues, social responsibilities, reporting, and risk management, accounting needs have changed (Carnegie \& Napier, 2010). Accountants play a vital role in organizations in fields related to social responsibilities, including reporting, transparency, moral discipline, adherence to laws, relationships with beneficiaries, and resource consumption. Social responsibility accounting includes compiling, measuring, and reporting social commitments and other transactions and the mutual effects of these transactions between corporations and their surroundings.

\section{Areas of Social Responsibility Accounting and Auditing}

The Organization of Economic Co-operation and Development defines the purpose of a CSR program as "to encourage the positive contributions that multinational enterprises can make to economics, environmental, and social progress and to minimize the difficulties to which their various operations may give rise" $(2003,11)$. This definition focuses on two important aspects of a CSR program, namely creation of social value through corporate activities (social value-added activities) and avoidance of conflicts between corporate goals and societal goals (societal consensus). Four areas of social activities have been identified:
i. Interaction between society and the organization
ii. Help to improve human resources
iii. Help to improve natural resources and environment
iv. Promote the quality of products (Gray, 2002; Jebreel,1999)

Rahahleh and Shariari (2008) categorized the social activities of organizations in which accountants are employed into four groups: 
i. Employee-based: the effects of organizational activities on employees as available human resources who help the organization to realize its goals

ii. Environment-based: social activities that reduce negative effects of organizational activities on the environment and natural resources. Given the potential damages to the environment caused by polluted soil, water, air, and acoustic pollution, this group is among the most important dimensions of social responsibility accounting.

iii. Supporting customers: activities aimed at satisfying customers and protecting their benefits. Examples include: product safety, advertisement reliability, and sufficient information to consumers about products, methods and limitations, related risks, and credit period.

iv. Society-based: activities aimed at achieving public benefits such as employing disabled people, student training, establishing kindergartens, improving health projects, and supporting charity projects.

\subsection{Goals of Social Responsibility Accounting and Auditing}

Ramanathan (1976) stated that the main goal of social responsibility accounting is to evaluate whether organizations have met their social responsibilities adequately or not. He stated three goals of social responsibility accounting, and various authors restated them in different ways:

i. To determine and measure a business' social performance during the financial period by calculating the social expenditures and profits of the business.

ii. To determine the relationship between current performance and the business' approaches, according to social measures and preferences.

iii. To report social performance and its effect on consumers' decisions.

iv. To provide information about the goals, policies, and social projects of the business and how it is meeting consumer needs. Disclosure of adequate CSR information is necessary in assessing a company's commitment to society.

The CSR program is designed to minimize the conflicts between corporations and society caused by differences between private and social costs and benefits and to align corporate goals with those of society. Examples of conflicts between corporations and society are related to environmental issues (pollution, acid rain, global warming), wages paid by multinational corporations in poor countries, and child labor in developing countries. Corporate governance measures, which include rules, regulations, and best practices of CSR programs, can raise companies' awareness of the social costs and benefits of their business activities. The benefits of a CSR program include addressing environmental matters, reducing waste, reducing risk, improving relations with society, and discouraging regulatory actions. CSR programs enable corporations to take proper actions to promote social good and advance social goals above and beyond creating shareholder value or simply complying with applicable laws and regulations (e.g. antipollution). CSR programs should promote a set of voluntary actions advancing the social good that go beyond the company's obligation to its various stakeholders. CSR activities should be measured and transparent, just as financial activities are measured and disclosed. Assurance should be provided on CSR reports through robust auditing of CSR activities, programs and reports.

\section{Social Responsibility and Sustainability}

Sustainability and social responsibility are key to the current business environment (State \& Popescue, 2008). Sometimes the term sustainability is used in place of CSR. Montiel (2008) investigated different definitions of sustainability and CSR and found that although they have different origins, they both relate financial responsibilities to social and environmental responsibilities. Some authors defined sustainability as an approach to conceptualize CSR. For example, Garriga and Mele (2004) tried to map the field of CSR and then considered sustainable development as an approach to conceptualize CSR. Some researchers have considered sustainability as meaning corporate environmental responsibility; most of the time they use the term environmental development (Sharma \& Henriques, 2005; Shrivastava, 1995). According to van Marrewijk and Werre (2003), there is no clear definition of sustainability, so each organization has to design its own definition according to its own goals. It seems that many corporations assume sustainability and corporate social responsibility are synonymous and based on voluntary activity, including paying attention to environment and society.

The social dimension of sustainability is related to organizational effects on social systems employed in an organization. Requirements for social performance are satisfied by reporting the organizational effects on stockholders and beneficiaries at the local, national, and global levels. Additionally, social factors affect 
intangible assets such as human resources. Social factors are mentioned in three areas: labor force activities, human rights, and social development. Zwetsloot (2003) proposed integrating CSR with continuous development ensuring sustainability.

\section{Components of CSR}

A survey conducted by one of the Big Four accounting firms identifies four key CSR topics: core labor standards, working conditions, community involvement, and philanthropy (KPMG, 2005).

i. Core labor standards: Core labor standards comprise a general commitment to human rights, the right to equality of opportunity and treatment, the right to freedom of association and collective bargaining, the prohibition of forced labor, the abolition of child labor, and commitment to diversity.

ii. Working conditions: Working conditions address the general working conditions of corporate facilities including working time and work organization, work and family, wages and income, occupational safety and health, stress and violence, harassment, and maternity protection.

iii. Community involvement: Community involvement addresses the extent to which a company fulfills its social concerns related to its operations and is involved with and values community interventions such as programs aimed at improved health and education services.

iv. Philanthropic programs: These programs tend to be less strategic than other forms of social involvement in terms of adding social and business values. The International Organization for Standardization (ISO) issued ISO 26000 in 2011 covering a broad range of an organization's activities, from economic to social, governance, ethics, and environmental issues. ISO 26000 is a globally accepted guidance document for social responsibility in assisting organizations worldwide to fulfill their CSR (ISO, 2010).

Social responsibility performance promoted in ISO 26000 is conceptually and practically associated with the achieving sustainable performance, because the fulfillment of social responsibility necessitates and ensures sustainable development. ISO 26000 goes beyond profit-maximization by presenting a framework for organizations to contribute to sustainable development and the welfare of society. The core subject areas of ISO 26000 take into account all the aspects of the triple bottom line: key financial and nonfinancial performance relevant to profit, people, and the planet.

i. Profit: The primary goal of business organizations has been and will continue to be to earn profit in a socially responsible way to ensure shareholder value creation and the achievement of the desired rate of return on investment.

ii. People: ISO 26000 encourages companies to recognize human rights as a critical aspect of social responsibility by ensuring the countries in which they operate respect the political, civil, social, and cultural rights of the citizens.

iii. Planet: ISO 26000 promotes sustainable resource management to ensure that business organizations are not exploiting the environment in which they are operating.

Brockett and Rezaee (2012) discuss the following provisions of ISO 26000 designed to help

business organizations operate in a socially responsible manner by providing guidance on:

- Concepts, frameworks, terms and definitions pertaining to CSR.

- Background, trends and characteristics and best practices of socially responsible organizations.

- Principles, standards and best practices relevant to CSR.

- Policies, procedures and best practices for integrating, implementing and promoting CSR.

- Engagement of all stakeholders, including shareholders, in socially responsible activities.

- Disclosure of information and nonfinancial KPIs related to social responsibility.

\section{Conclusion}

CSR requires business organizations to take initiatives to advance some social good beyond their own interests and compliance with applicable regulations. Simply put, CSR means enhancing corporations' positive impacts and minimizing negative effects on the community, environment, employees, customers, and suppliers. The true measure of success for corporations should not only be determined by reported earnings, but by their governance, social responsibility, ethical behavior, and environmental initiatives. CSR is a vital part of commerce. Companies must perform corporate supervision transparently, and reports are very important to realizing these goals. 
Managers of future international companies are forced to persuade the public to trust them. Governments are responsible for finding solutions or methods to bridge barriers, integrating them with the international economy, and entering the World Trade Organization.

Business managers who pay attention to CSR and perform current activities according to social responsibility raise the quality of their businesses. Recent trends in business reporting have paid attention to nonfinancial disclosure. Stakeholders expect each company to meet minimal governance and disclosure standards. During this evolutionary process at the international level, obligatory disclosure of financial information is integrated with voluntary financial and nonfinancial disclosure.

Nowadays, companies are expected to be committed to the long-term needs of society. Basically, companies must participate in those activities that reduce the negative effects of their operations and increase the social benefits. Some plans have been introduced by government and the private sector, but there is not yet any model or standard. Therefore, academic and professional departments must provide financial support to solve this issue. They must prepare the required instruments for authorities to enforce standards for disclosing, reporting, and auditing CSR.

Accountants play a vital role in organizations in fields related to social responsibility, including reporting, transparency, moral discipline, compliance with laws, relationships with beneficiaries, and resource consumption. Social responsibility accounting must include revealing information to beneficiaries, providing feedback for management, and improving environmental projects. Because social responsibility accounting information is not financial data, the information can often be found in the explanatory sections of annual reports, not in the main reports. Modern businesses need to work toward sustainability, making sure that availability of resources in the future will not be limited by current decisions. As Montiel (2008) found, although sustainability and CSR have different origins, they both relate financial responsibilities to social and environmental responsibilities. The social dimensions of sustainability are related to organizational effects on social systems employed in organizations. Requirements for social performance are satisfied by reporting the organizational effects on stockholders and beneficiaries at the local, national, and global level. The true measure of success for corporations should be determined not only by their reported earnings, but also by their governance, social responsibility, ethical behavior, and environmental initiatives. CSR has received considerable attention from policymakers, regulators, and the business and investment community over the past decade, and it is expected to remain a central theme for decades to come.

\section{References}

Anderson, J. W., Jr. (1989). Corporate social responsibility: Guidelines for top management. New York, NY: Quorum Books.

Aras, G., \& Crowther, D. (2008). Governance and sustainability: An investigation into the relationship between corporate governance and corporate sustainability. Journal of Management Decision, 46(3), 433-448. http://dx.doi.org/10.1108/00251740810863870

Aupperle, K. E. (1984). An empirical measure of corporate social orientation. Research in Corporate Social Performance and Politics, 6, 27-54.

Baron, D. (2001). Private politics, corporate social responsibility and integrated strategy. Journal of Economics and Management Strategy, 10, 7-45. http://dx.doi.org/10.1162/105864001300122548

Bowen, H. R. (1953). Social responsibilities of a businessman. New York, NY: Harper and Row.

Brockett A. M and Z. Rezaee. 2012. Corporate Sustainability: Integrated Performance and Reporting. John Wiley and Sons, (November) New York, USA.

Carnegie, G. D., \& Napier, C. J. (2010). Traditional accountants and business professionals: Portraying the accounting profession after Enron. Accounting, Organizations and Society, 35(3), 360-376. http://dx.doi.org/10.1016/j.aos.2009.09.002

Carroll, A. B. (1991). The pyramid of corporate social responsibility: Toward the moral management of corporate stakeholders. Business Horizons, 34(July-August), 39-48. http://dx.doi.org/10.1016/0007-6813(91)90005-G

Carroll, A. B. (1999). Corporate social responsibility: Evolution of a definitional construct. Business and Society, 38(3), 268-295. http://dx.doi.org/10.1177/000765039903800303 
Clarkson, M. B. E. (1999). A stakeholder framework for analysing and evaluating corporate social performance. The Academy of Management Review, 20(1), 92-117.

Committee on Social Measurement. (1977). The measurement of corporate social performance. New York, NY: American Institute of Certified Public Accountants.

Davis, K. (1973). The case for and against business assumption of social responsibilities. Academy of Management Journal, 16, 312-322 http://dx.doi.org/10.2307/255331

Defillipi, R. J. (1982). Conceptual framework and strategies for corporate social involvement research. In L. E. Preston (Ed.), Research in corporate social performance and policy, No. 4. Greenwich, CT: JAI Press.

Drucker, P. F. (1977). People and performance. New York, NY: Harper and Row.

Frankental, P. (2001). Corporate social responsibility—a PR invention. Corporate Communications: An International Journal, 6(1), 18-23. http://dx.doi.org/10.1108/13563280110381170

Frederick, W. C. (1994). From CSR1 to CSR2: The maturing of business-and-society thought. Business \& Society, 33(2), 150-164. http://dx.doi.org/10.1177/000765039403300202

Freeman, R. E., Wicks, A. C., \& Parmar, B. (2004). Stakeholder theory and "the corporate objective revisited. Organization Science, 15(3), 364-369. http://dx.doi.org/10.1287/orsc.1040.0066

Friedman, M. (1970, September 13). The social responsibility of business is to increase its profit. New York Times Magazine, pp. 32-33, 122-123.

Garriga, E., \& Melé, D. (2004). Corporate social responsibility theories: Mapping the territory. Journal of Business Ethics, 53, 51-71. http://dx.doi.org/10.1023/B:BUSI.0000039399.90587.34

Gray, R. (2002). The social accounting project and accounting organizations and society: Accounting is applied in the financial statements of companies in Gaza Strip. Journal of Islamic University, Human Studies Series, 15(1), 239-281.

Gray, R., Owen, D., \& Maunders, K. (1987). Corporate social reporting: Accounting and accountability. London: Prentice-Hall.

http://public.wsu.edu/ susdev/WCED87.html, Sustainable Development: From Brundtland to Rio 2012 (2013-09-13).

International Organization for Standardization (ISO). (2010). ISO 26000, Social responsibility. Retrieved from http://www.iso.org/iso/iso_catalogue/management_and_leadership_standards/social_responsibility/sr_iso26 000_overview.htm\#sr-1

Jebreel, N A. (1999). Responsibility accounting in Jordanian industrial public joint stock companies—-field study (Unpublished MA thesis). Faculty of Economics and Administrative Sciences, Al al-Bayt University, Mafraq, Jordan.

Jones, T. (1983). An integrating framework for research in business and society: A step toward the elusive paradigm? The Academy of Management Review, 8, 559-564. http://dx.doi.org/10.2307/258257

Joyner, B. E., \& Payne, D. (2002). Evolution and implementation: A study of values, business ethics and corporate social responsibility. Journal of Business Ethics, 41(4), 297-311. http://dx.doi.org/10.1023/A:1021237420663

KPMG International. (2005). Survey of corporate responsibility reporting. Retrieved from http://www.kpmg.com

Lee, M. (2008). A review of the theories of corporate social responsibility: Its evolutionary path and the road ahead. $\begin{array}{lllll}\text { International Journal of } & \text { Management }\end{array}$ http://dx.doi.org/10.1111/j.1468-2370.2007.00226.x

Marrewijk, M. van, \& Werre, M. (2003). Multiple levels of corporate sustainability. Journal of Business Ethics, 44(2/3), 107-119. http://dx.doi.org/10.1023/A:1023383229086 
Meehan, J., Meehan, K., \& Richards, A. ( 2006). Corporate social responsibility: The 3C-SR model. International Journal of Social Economics, 33(5/6), 386-398. http://dx.doi.org/10.1108/03068290610660661

Novak, M. (1996). Business as a calling: Work and the examined life. New York, NY: The Free Press.

Organization of Economic Co-operation and Development. (2003). Guidelines for multinational enterprises. Retrieved from http://www.oecd.org

Orlitzky, M., \& Benjamin, J. D. (2001, December). Corporate Social Performance and Firm Risk: A $\begin{array}{llll}\text { Meta-Analytic Review. Business and } & \text { 369-396. }\end{array}$ http://dx.doi.org/10.1177/000765030104000402

Pettenella, D. (2010). CSR: What it is, what issues it incorporates? What costs/benefits of implementation? Paper presented at United Nations Economic Commission for Europe, UNECE Workshop on Corporate Social Responsibility. Belgrade, Serbia, 13-14 April.

Preston, L. E., \& Post, J. E. (1975). Private management and public policy: The principle of public responsibility. Englewood Cliffs, NJ: Prentice Hall.

Rahahleh, M., \& Shariari, J. (2008). The extent of social responsibility accounting application in the qualified industrial zones in Jordan. Journal of International Management Review, 4(2), 5-17.

Ramanathan, K. (1976). Towards a theory of corporate social responsibility accounting. Accounting Review, 1(3), 516-527.

Rezaee, Z. 2015. Business sustainability: Performance, Compliance, Accountability and Integrated Reporting. Greenleaf Publishing Limited, October 2015.

Rubenstein, D. (1992). Bridging the gap between green accounting and black ink. Accounting Organizations and Society, 17(5), 501-508. http://dx.doi.org/10.1016/0361-3682(92)90044-S

Sethi, S. P. (1975). Dimensions of corporate social performance: An analytical framework. California Management Review, 17(3), 58. http://dx.doi.org/10.2307/41162149

Sharma, S., \& Henriques, I. (2005). Stakeholder influences on sustainability practices in the Canadian forest products industry. Strategic Management Journal, 26(2), 159-80. http://dx.doi.org/10.1002/smj.439

Shrivastava, P. (1995). Environmental technologies and competitive advantage. Strategic Management Journal, 16(S1), 183-200. http://dx.doi.org/10.1002/smj.4250160923

Smith, N. C. (2003). Corporate social responsibility: Not whether, but how? Centre for Marketing Working Paper No. 03-701.

Solomon, R. (1994). The new world of business: Ethics and free enterprise in the global 1990s. Lanham, MD: Rowman and Littlefield Publishers.

State, O., \& Popescu, D. (2008). Leadership and social responsibility. Amfiteatru Economic, 10(23), 72-79.

Tuzzolino, F., \& Armandi, B. R. (1981). A need-hierarchy framework for assessing corporate social responsibility. The Academy of Management Review, 6(1), 21-28.

United Nations Environment Programme Finance Initiative and the UN Global Compact. (2006, April 27). Principles for responsible investment. Retrieved from www.unepfi.org/principles

United Nations Principles for Responsible Investment (PRI) initiative. The six principles. Retrieved from http://www.unpri.org/about-pri/the-six-principles/

Votaw, D. (1973). Genius becomes rare. In D. Votaw, \& S. Sethi (Eds.), The corporate Dilemma. Prentice Hall: Englewood Cliffs, NJ.

Walton, C. C. (1967). Corporate social responsibilities. Belmont, CA: Wadsworth.

Windsor, D. (2001). The future of corporate social responsibility. International Journal of Organizational Analysis, 9(3), 225-256. http://dx.doi.org/10.1108/eb028934 
Wood, D. J. (1991). Corporate social performance revisited. The Academy of Management Review, 691-718 .

Zwetsloot, G. (2003). From management systems to corporate social responsibility. Journal of Business Ethics, 44(2/3), 201-207. http://dx.doi.org/10.1023/A:1023303917699

\section{Copyrights}

Copyright for this article is retained by the author(s), with first publication rights granted to the journal.

This is an open-access article distributed under the terms and conditions of the Creative Commons Attribution license (http://creativecommons.org/licenses/by/3.0/). 